\title{
The agency origins of insider trading
}

\author{
Sinclair Davidson and David Solomon \\ Department of Business Economics, University of the Witwaterstand, P.O. Wits 2050, Republic of South Africa
}

Received 29 July 1991, accepted 30 September 1991

\begin{abstract}
Insider trading has been a topical issue in recent times. While the debate regarding insider trading usually extends to economic and ethical arguments in favour of or against the practice, in this article we attempt to ascertain the causes of the practice. The origins of insider trading are traced to the separation of ownership and control. It has been argued that insider trading is beneficial to minority shareholders and reduces the agency cost problem; this is shown to be fallacious. The authors conclude that insider trading is an agency problem and that the disciplinary mechanisms described in the literature do not inhibit the phenomena, indeed some of these mechanisms actually facilitate the occurrence of insider trading. This it is argued provides the rationale for government intervention and anti-insider trading legislation.
\end{abstract}

\begin{abstract}
Binnekringtransaksies het onlangs heelwat opspraak gewek. Die debat cor binnekringtransaksies bestaan hoofsaaklik uit die aanvoer van ekonomiese of etiese argumente vir of teen die praktyk. In hierdie artikel word gepoog om die oorsake van hierdie praktyk vas te stel. Die oorsprong van binnekringtransaksies word teruggevoer na die skeiding van eienaarskap en beheer. Daar is al aangevoer dat binnekringtransaksies tot die voordeel van minderheidsaandeelhouers strek, aangesien dit die agentskapsprobleem verminder, maar in hierdie artikel word aangetoon dat dit nie die geval is nie. Die skrywers kom tot die gevolgurekking dat binnekringtransaksies 'n agentskapsprobleem is en dat die meganismes, wat volgens die literatuur hierdie praktyk aan bande behoor te lê, dit in werklikheid vergemaklik. Daar word ook aangevoer dat die beweegrede vir optrede deur die staat, asook wetgewing om binnekringtransaksies te bekamp, hieruit voortspruit.
\end{abstract}

'Economic discussions of the agency problem ... are both enlightening and frustrating: enlightening because they show how difficult it is to induce agents to act in principals' interests, and frustrating because they do not establish whether the solutions they describe are effective' (Easterbrook, 1985: 81).

\section{Introduction}

Insider trading is said to occur when a person (termed the insider) buys or sells shares in the market based on 'material inside information'. It is a very broad definition, in that the concepts involved are vague. Who is an insider and what is material information, remain questions that have no precise answers.

In the United States of America (USA) an insider is 'a corporate director, officer, or shareholder with more than ten percent of the shares of that company'. It also includes the relatives of the above, and, 'any other person who takes advantage of inside information' (Ryan 1988: 58-59). This definition is relevant to the South African experience as the new law on insider trading (s44OF of the Companies Act) is based on the US law. This definition covers all possible users of inside information. It is interesting to note that even tippees, no matter how far removed from the source of the information are still 'guilty' of insider trading.

Information is said to be material if it would lead to the market revising the price of a particular share, if that information were generally known. It is also material if it would impact significantly on the investing public's decision-making processes as to whether or not to invest in or divest from that share (Clark 1986: 264). Those areas and types of information which could be described as inside information include inter alia:

- negotiations with respect to mergers and acquisitions;

- share splits;

- tender offers;
— earnings and dividends;

- new investments;

- capital restructuring;

- changes in management; and,

- disinvestment and management buy-outs.

In this article, we analyse insider trading as an agency problem. We will attempt to demonstrate that the mechanisms referred to in the literature are generally insufficient to curb insider trading. In many situations these mechanisms actually facilitate the occurrence of insider trading. It might thus be argued that insider trading plays a role in ensuring the efficiency of the firm. As such insider trading should show some benefits to the shareholders or the firm. We also discuss the arguments for and against insider trading and demonstrate that this is not the case. Insider trading is neither beneficial to the shareholders, firm, or society at large. While recognising the need for insider trading to be regulated we make no specific recommendations as to the exact form this regulation should take.

This article is divided into three sections, in the first we review the current debate regarding insider trading. In the second section we consider the origins of insider trading using agency cost analysis. A conclusion follows.

\section{Efficiency and insider trading}

'Efficiency is my primary concern' - Harold Demsetz (1969: 16).

\section{Benefits of insider trading}

The so-called 'moral dwarfs' (Easterbrook, 1985: 83) of the insider trading debate have come up with some ingenious arguments in favour of insider trading. As will be seen, none of these is able to stand up to close scrutiny. In this section we examine these theories.

The various writers usually advance the following arguments in favour of insider trading: 
- it rewards entrepreneurs;

- it enhances market efficiency;

- it provides an incentive to discover information; and,

- it promotes confidence in the market.

Related arguments include:

- no firm has ever forbidden the practice; and,

- insider trading has survived for a long time.

Schumpeter (1942; in Manne 1966b: 117) argued that forms of compensation for entrepreneurs other than salaries and bonus', were generally illegal. He further stated that entrepreneurs required unconventional and less certain forms of compensation. When this was not forthcoming, entrepreneurs would exit the markets and disappear from the corporate world. Bhana (1989: 143) however states that empirical evidence has not shown this to be true and Schumpeter was wrong.

Manne (1966a, 1966b) argues that insider trading is the reason that Schumpeter was wrong. Insider trading allows the entrepreneur/innovator to be rewarded for his skills. Manne (1966b: 118) submits that the increase in share price resulting from an innovation is a measure of that person's worth to the firm.

An important consequence of this would be to align shareholders' and managements' interests, i.e. it rectifies what we now call agency costs (Easterbrook 1985: 83). Managers could profit from exceeding market expectations about the firm and would compensate the shareholders by taking a cut in salary. This cut in salary would off-set the losses incurred in insider trading by investors. In this way compensation is linked to performance and not to position in the hierarchy.

The concept of managers taking a cut in salary is popular in the literature. Demsetz (1983: 379) states that 'the owner-manager pays for his amenities by accepting a reduction in his implicit managerial compensation'. Fama (1980: 296) talks about 'ex post settling up'. This basically means that at the end of the contractual period, the firm will pay the difference between what it promised to pay the manager and the monetary value of his on-the-job consumption. Klein correctly points out that this may not be feasible.

'(I)n many cases letting the agent shirk and discounting his wage will not be an economical solution because the gain to the shirker and therefore his acceptable compensating wage discount is less than the cost to the firm from the shirking behaviour' (1983: 368).

In any event this argument is not compatible with the Manne argument. Manne views insider trading as a form of compensation, why then should there be any form of ' $e x$ post settling up'? The 'settling up' argument implies a sense of wrong doing, to our mind it is an 'admission of guilt'.

Clark (1986: 277-280) states that there are at least six objections to Manne's argument:

- it is 'implausible to believe' that compensation packages are inadequate to induce vigorous managerial performance;

- managers who trade on inside information are able to profit from both good and bad management;

- there is no guarantee that only entrepreneurs benefit from insider trading;
- the large size of the modern firm trivialises the impact one individual can have on share prices;

- a systematic bias against prompt disclosure may emerge; and,

- the resources expended on the 'pursuit of individual profit-making through insider trading' would be wasted.

This last objection seems to indicate that instead of 'curing' the agency problem, insider trading simply adds fuel to the fire.

We submit that Schumpeter was wrong per se, and capitalism has not been saved by subsequent events, or by some unforseen variable. The market is a very resilient social institution. While it may be distorted by government intervention, we cannot believe that it will be destroyed by either its failings or its success. Demsetz (1967) has demonstrated that whenever the market begins to give rise to sub-optimal equilibria, property rights change in order to correct the situation.

Demsetz (1986) considers the situation of large family holdings in firms. This argument is a derivative of the argument above. He states that often these 'controlling shareholders' have specialised portfolios and are thus exposed to firm-specific risk (unique or unsystematic risk). Demsetz (1986: 313) gives two reasons for this:

- they have a 'comparative advantage in exercising control'; and,

- they may be 'locked in' to control by factors such as taxation.

Demsetz does not rely on the second reason and only examines the first.

Demsetz (1986: 313 ) submits that 'insider trading offers a secondary compensation to controlling shareholders'. These controlling shareholders or insiders bear 'special' costs as a result of their large holdings and control. Thus the abnormal returns earned by insiders are not abnormal at all! They are simply greater compensation for higher costs and Demsetz argues that these returns

'cannot be interpreted to mean that controlling shareholders receive a higher personal return than is enjoyed by outsiders' (emphasis original) (1986: 316).

Trading on inside information and the wealth transfers associated with it, is the way in which controlling shareholders are compensated, i.e. the minority shareholders are 'paying' insiders a premium 'to encourage more effective monitoring of the firm' (Demsetz 1986: 315). Those shareholders that trade frequently are going to bear the brunt of this premium. If minority shareholders wish to avoid this, they should follow buy-and-hold investment strategies. This type of strategy imposes illiquidity costs on both the investor and the market in general. We submit that minority shareholders will either avoid these shares totally or will discount the probability on insider trading into the price, either way the cost of capital for these firms will be increased.

Kantor (1991: 170) submits that the right to trade on the inside in these cases would be part of an implicit contract between managerial and non-managerial shareholders. We submit that the only contract between the firm and its shareholders and between the shareholders inter se, exists in the memoranda and (especially) the articles of association. Even if such a contract did exist the provisions of the 
contract with respect to insider trading would be void.

Scott (1980: 808) argues that insider trading amounts to paying managers by lottery tickets. The only constraint to infinite profits is the managers' ability to raise finance and their ability to buy sufficient shares at a profitable price. This brings a great deal of uncertainty into the implicit contract. This uncertainty invalidates the implicit contract and in any event shareholders would be unlikely to agree to such a contract. Clark (1986: 274) submits two reasons for this:

- the remuneration taken by managers may be more than shareholders feel that they are worth; and,

- even if inside profits were equal to the desired remuneration, the increased levels of uncertainty would be 'avoidable, unnecessary, and unproductive'.

As far as Demsetz and Kantor are concemed, we submit that minority shareholders are not going to be impressed by their arguments. With respect to the entrepreneurial reward theory, we concur with Clark when he states:

'(t)he argument seems quite strained ... Both the allegedly excessive fear of risk taking and the assumed inability to deal with it in some other way ... seem doubtful to me' (1986: 278).

We do not think that insider trading is the saviour of capitalism or the only way that entrepreneurs or managers can be compensated.

The argument that insider trading makes the market more efficient can be combined with the argument that it increases investor confidence. The concept of efficiency refers to the efficient markets hypothesis (in the strong form). Insider trading ensures that prices tend towards their intrinsic values before announcement dates and so, the market tends to become efficient in the strong form. Kantor (1991: 168) argues that insiders cause information to enter the market continuously. If insiders compete with each other for insider rents then insider profits will be quickly exhausted and thus outsiders would be protected from the vagaries of an inefficient market because the new price would be the 'correct' one.

Kantor provides us with a paradoxical statement.

'If the prohibition on insider trading is effective and the price changes dramatically upon announcement, any seller or buyer who unwittingly acted before the announcement would have sold or bought at the wrong price. If the news is good, outside buyers will have enjoyed a windfall gain, but outside sellers would have suffered an equivalent windfall loss. Such consequences of incomplete information could hardly be called fair' (1991: 168).

This is very strange coming from Kantor who describes himself as a supporter of Manne (who scorns arguments based on fairness). Kantor is saying that it is unfair to benefit from the fact that the market is inefficient. He gives no reason why it is any less unfair that insiders should be the recipient of this windfall gain. After all, they too are trading when the market is inefficient!

The argument that insider trading provides an incentive to discover information is similar to the 'entrepreneur incentive' argument. Easterbrook (1985: 84) argues that insiders have an incentive to discover information before anyone else. He adds that perhaps firms are poor internal communicators of information and that management has to seek out information from subordinates. If top management can trade on inside information, then instead of waiting for information to reach them through the bureaucratic pipeline, they will take a greater interest in information creation.

This argument is intuitively appealing in that insider trading would provide the necessary incentive were Easterbrook correct. A reading of the agency-literature (esp. Fama 1980 and Fama and Jensen 1983a, 1983b) indicates that while the firm is awash with information (and conceivably is a poor communicator of that information), that strategic information is concentrated in the upper reaches of the organisation. The scope for trading on operational information, which the manager needs to discover, is limited. As such this argument has only an extremely limited scope.

An argument often posed is, 'Why don't firms adopt prohibitions against insider trading in their memoranda and articles of association?'. Proponents of insider trading argue that this is because shareholders do not really want prohibitions on insider trading. Clark (1986: 275) points out, however, that firms have similarly not prohibited fraud or theft. Reasons for this include:

- the law already outlaws this type of behaviour, and,

- people believe that insider trading is immoral and see no reason to have to contractualize their moral beliefs.

Insider trading has been described as 'finance's oldest profession' (Wixley 1990: 40). The argument that insider trading has survived for so long is that if it were inefficient it would no longer exist.

'Firms made little or no effort to suppress such trading. If it is an inefficient method of compensation, why did it not go away?' (Easterbrook, 1985: 90).

Easterbrook states that the legal literature ascribes this to persistent advantage taking. Two further points should be made:

- rape and murder have survived for even longer than insider trading; and,

- perhaps this demonstrates that insider trading is not a form of compensation at all, but just an efficient form of expropriation.

The point here is that simply because a phenomena has persisted for a long time there should be no prima facie argument that the activity is beneficial to society.

Clark (1986: 276) submits that insider trading causes little obvious harm to the firm, but as a whole creates a great deal of 'unproductive uncertainty that reduces the efficiency of the securities markets'. Thus on a cost-benefit basis it may not pay individual firms to prohibit insider trading. In any event, there is litule incentive for management to curb insider trading, as they usually are the insiders or at least the source of tips.

\section{Harm of insider trading}

Having demonstrated that insider trading is not beneficial to shareholders or the firm, what remains to do is demonstrate that insider trading is harmful. It is not enough to show that insider trading is not beneficial, in order to justify the costs of regulation, we must show that insider trading is harmful to the market and investors. 
The arguments against insider trading include: - it creates a systematic bias against prompt disclosure; - it harms investor confidence;

- it makes the market illiquid;

- it raises the cost of capital; and,

- it creates an incentive to create 'bad' information.

The need for prompt disclosure stems from the desire for an efficient market. With an efficient market we can be sure that scarce resources are allocated to their highest value uses.

Insider trading does disclose information to the market, in the form of increasing or decreasing prices. However, the Commissioner Grundfest of the Securities Exchange Commission (SEC) has this to say:

'Sooner is not necessarily better when it comes to information disclosure. There is an optimal point at which information should be disclosed and it can be inefficient if information is disclosed either too soon or too late. In general, it seems that the owner of the information is the party best suited to determine the optimal time for disclosure and insider trading that forces premature disclosure may well work against the larger interests of corporations and their shareholdings' (quoted in Sturc, 1987: 408).

Harris (1988: 22) argues that management is in the best position to determine this 'optimal point' in time. However, management themselves are often the insiders. Thus, some form of direct disclosure would be more efficient and equitable then than indirect disclosure. Benston (1969: 25-26) argues that prompt disclosure is more efficient than insider trading under the following conditions:

- management may be dishonest and may attempt to mislead the investing public;

- management may be mistaken about the marginal costs and benfits of financial statements; and,

- the firm may enjoy economies of scale in the provision of information.

While each of these conditions do not always hold, we submit that some of them must prevail at least some of the time. The major advantage of disclosure over insider trading is that information can be evaluated before announcement.

'You can't ascribe a quality to information that is only partial, rumours change and have no veracity or precision' (Norton, quoted in Wixley 1990: 42).

Insider trading causes investors to lose confidence in the market and thus cease trading. This causes the market to become illiquid. This then undermines the capitalist order.

'When investors are driven from the market, the market becomes less liquid, and thus less able to fuel the expanding capital demands of free enterprise' (B. Thomas of the SEC, quoted in Seligman 1983: 47).

It has been estimated that if present trends persist, the last share owned by an individual will be sold in 2003 (Light 1989: 62). While we cannot say that individual investors are exiting the market only because of insider trading, it does seem reasonable to argue that investors have less confidence in the market now than in the past. Insider trading would play a role in undermining that confidence. Norton certainly subscribes to this view:
'Insider trading should be regarded as merely one element in the broad portfolio of considerations relevant to achieving deep and liquid markets... public perception is as important as reality...' (quoted in Wixley 1990: 42).

If insiders wish to benefit from on-the-job consumption, they have to pay for it. Investors will demand a higher rate of return on their investments. The form that this takes is a reduction in share price and consequently an increase in the cost of capital. If the demand for capital is price elastic, the increased cost of capital will mean that there will be less investment and capital formation (Clark 1986: 274).

The incentive to create artificial news is great, as insiders can profit from it. While it is impossible to fool everyone all of the time, it is possible to fool everyone some of the time. If management can create false news and trade on it, then we cannot, at all, say that insider trading makes the market more efficient.

This concept is not as esoteric as it sounds. In the US case, SEC versus Texas Gulf Sulphur (quoted in Parkman, George and Boss 1988: 968) management issued an ambiguous statement and then traded on the (false) information. Similarly, in the US case, SEC versus Shattuck Denn Mining Corporation (quoted in Clark 1986: 278), the firm's president sold his shares in the firm before correcting a 'false and misleading press release'.

The threat of false information would, again lead to inefficiency on the stock market. The way to circumvent this problem is to have regular audited financial disclosures. This, not insider trading, would lead to greater efficiency.

'The provision of more effective disclosure might have no discernable effects on the results of random walk tests but would be expected to bring market price closer to its long-run equilibrium value' (Friend 1969: 241).

We have seen that all the arguments against insider trading boil down to the fact that it harms confidence and efficiency. In an economic analysis we would compare the alleged gains to efficiency losses and depending on net efficiency would decide on whether insider trading were desirable or not. We submit that the answer to such a tradeoff would be against insider trading. However, it would be immaterial what the answer is. The question of investor confidence is vital. The facts are irrelevant, as long as investors perceive insider trading to be prejudicial to their interests they will refuse to participate in the market. In the final analysis, this is a source of inefficiency. Until the proponents of insider trading can address this particular problem, their views will and must remain in the economic and policy wildemess.

\section{The theory of the firm}

What we wish to do is to consider the firm from an organizational point of view, specifically the nexus of contracts approach in the Coasian tradition in which the basic unit of analysis is the transaction and the contractual relationships established by transactions. Williamson defines a transaction as:

'when a good or service is transferred across a technologically separable interface. One stage of proces- 
sing or assembly terminates and another begins' (1981: 1544).

Faith, Higgins, and Tollison define contracts as:

'an allocation of rewards over states of the world and over actions of the contracting parties. An efficient contract will assign rewards based on joint actionstate contingencies in order to provide incentives for value-maximizing actions, provided that the costs of contracting ... are not prohibitive. An efficient contract maximises the expected net gains from trade.... Because it is costly to write and enforce completely specified contracts, many contract terms are left implicit' (1984: 661).

Arrow (1969; in Williamson 1981: 1543) refers to transaction costs as the 'costs of running the economic system'.

These costs arise because of what Williamson (1981) refers to as 'bounded rationality' and 'opportunism'. Bounded rationality refers to the fact that individuals are not perfectly rational. They 'experience limits in formulating and solving complex problems and in processing ... information' (Simon quoted in Williamson 1981: 1545). Opportunism refers to self-interest, extending to self-interest with guile. That is to say that individuals can and will resort to deceit in order to further their own self-interest. This is not to say, however that all opportunism involves deceit. Williamson states:

'But for the simultaneous existence of both bounded rationality and opportunism, all economic contracting problems are trivial... (B)ut for bounded rationality, all economic exchange can be effectively organised by contract' (emphasis original) (1981: 1545).

While research into the so-called agency problem has only recently 'taken off', economists have long recognised the problem. Adam Smith wrote that

'directors of (joint-stock) companies, however, being the managers of other people's money rather than their own, it cannot be expected, that they should watch over it with the same anxious vigilance with which the partners in a private (firm) frequently watch over their own' (1776: 770).

Jensen and Meckling (1976: 308) define the agency relationship in legal terms. A principal engages an agent to perform a service on his behalf, this occurs through the principal delegating some authority to the agent. If both the principal and the agent are rational and welfare maximizers we would expect there to be divergences in interests between the two. The principal, they claim, will incur monitoring costs in order to minimize these divergences. The agent, too, will incur bonding costs to reassure the principal of his 'loyalty'. They define the agency costs to be the sum of:

- monitoring costs;

- bonding costs; and,

- residual loss.

The residual loss is defined as the principal's loss in welfare brought about by the agent attempting to maximize his own, as opposed to the principal's welfare function.

In the absence of monitoring and bonding costs the agent would maximise his own welfare function at the expense of the principal i.e. the residual loss would be high. The principal, however, would be aware of this and would be unwilling to incur the expense of this opportunistic behaviour. As such he would pay less for the agent's services, in the context of the firm this translates into a lower share price. (This is the basis for arguing that insider trading increases the cost of capital.) In essence, Jensen and Meckling are saying that there are no free lunches or unconstrained potential for opportunistic behaviour. In this approach the capital market is the mechanism that ensures that the agency problem is minimized.

In order to provide a greater understanding of the firm, Fama (1980: 290) separates the concepts of decision making and risk bearing. The risk bearers (shareholders) simply own a single, albeit an important, input of the firm as a whole. Due to the concept of diversification, shareholders should be indifferent to the fortunes of any particular firm held in their portfolio, as all unsystematic risk will be diversified away.

Management, unlike the risk-bearers, are not indifferent to the fortunes of the firm. Large parts of their wealth are tied up in the fortunes of the firm. Fama (1980: 295) argues that the market for managers ensures the viability of the firm. This approach involves managers creating a 'brand name' for themselves. If the firm fails due to managerial incompetence then that manager's (or team of managers) career is over. The capital market, which allocates risk, also plays a role in retarding managerial indiscretion as this indiscretion will be capitalized into the value of the firm, i.e. the value of the firm's shares will be less than we would expect (this is Jensen and Meckling's point).

The market for managers can be divided into two separate markets, namely, an internal and external market. In the internal market, managers within the firm compete amongst themselves for better positions. Managers monitor each other, above and below themselves. The external market consists of those situations where managers are brought into managerial positions from outside the firm, i.e. from managerial positions in other firms. The apex of this monitoring structure is the board of directors. Fama (1980: 293) argues that the 'top' managers are the 'best' ones to control the board of directors.

The inclusion of outside directors ensures that the internal directors do not collude among themselves in order to expropriate shareholder wealth. In tum, the market for external directors ensures that they at least act in the shareholders interests. Fama (1980: 293) describes the board of directors as the ultimate internal monitor.

Fama builds hierarchy upon hierarchy, market upon market, and does so without apparent reason. In a later article he (in collaboration with Jensen) builds upon his argument and makes his position clearer.

Fama and Jensen (1983a: 303) concentrate on decision making. They identify four steps in any decision-making process:

- initiation;

- ratification;

- implementation; and,

- monitoring.

They define initiation and implementation as decision management, ratification and monitoring are defined as decision control.

In a 'complex' organisation, decision management will 
be diffused among many different agents throughout the firm. With this comes the fact that decision control will also be diffused throughout the firm. Ultimate control will vest in the board of directors. This will ensure that information is used efficiently by the relevant agents. This also creates opportunities for insider trading.

The impact of a hierarchical decision-making process is to ensure that individual agents do not expropriate the resources of the firm. Mutual monitoring should limit opportunistic behaviour, as acquiring a bad reputation (brand name) for excess on-the-job consumption will not enhance future career prospects.

Fama and Jensen (1983a: 313) identify three market related structures that alleviate agency problems:

- the board of directors, this is the internal "court of final appeal';

- the stock market, this provides an unbiased estimate of the implications of decision making on future cash flows; and,

- the market for takeovers, this is the external "court of final appeal'.

In order to monitor the board Fama and Jensen expect to see outside directors on the board. When the internal monitoring process breaks down, then and only then, should the shareholders resort to the external market, i.e. the market for takeovers.

These approaches all compliment each other and provide an internally consistent theory of the firm that is both consistent with the observed world and intuitively simple. It would appear that given this theory that all fears concerning the concept of separation of ownership and control should be laid to rest. In the next section we will demonstrate that perhaps this complacency is ill-founded.

\section{Insider trading in the firm}

Insider trading can form one of the components of managerial behaviour that comprise agency costs. The mechanisms described above may rectify the problems of nonwealth maximisation i.e. managers preferring growth over profits, or other objectives. They do not explicitly address the problem of insider trading. If all information leads to the board of directors then there is nothing stopping each and every one of them from trading on that information. If information is diffused throughout the firm, as Fama and Jensen argue, then there is nothing to prevent any agent in any part of the decision-making process (including secretaries, messengers or even the agents confidants) from doing the same. The structure of the modern firm through its diffusion of information actually facilitates insider trading.

In an impersonal market, such as the stock exchange, who is to know the origin of shares placed onto the market? Any internal or even external director may place shares on the market, without any of his colleagues realising the event. In the mechanisms described above, there is no way of keeping track of what any director or any other agent is doing to his portfolio or how he may be acting through proxies.

Even in the event of a takeover, the so-called 'final court of appeal', directors are still able to profit from their positions. Indeed they have an incentive to do so; as they may exit the board of directors in the near future. Here we see the absolute failure of a disciplinary mechanism to curb insider trading. In the case of a takeover the agent has the potential to earn profits that are limited only by his ability to mobilize resources. It could be argued that this is a method of compensating the agent for the potential (imminent) loss of office. However, given that the firm is soon to be in the throes of takeover, it would seem that the directors have not been maximizing profits and as such should not be so compensated.

A further argument as to the failure of this mechanism to curb insider trading comes from the fact that insider trading before a takeover can so increase share price that the takeover is abandoned. The manager/director who fears losing his job has an incentive to trade on the inside hoping that the takeover will fall through. In no way can this be described as acting in the interests of the shareholders or of the firm. This is a definite form of inefficiency.

In summary we argue that: insider trading occurs because of the structure of the firm and because no effective internal mechanism exists to arrest it. Managers trade on inside information because they can profit from it personally. Furthermore, in the absence of regulations or the presence of ineffective regulations, they can do so undetected.

Even if managers entered into contracts with the firm not to trade on inside information, they would still have an incentive to do so to the extent that they could get away with it. They might even break their contracts to do so. Perhaps a modern version of Hobbes' theorem can be found in Alchian and Woodward:

'When a conflict arises between what people want to do and what they have contracted to do for others, they will act in their own interest insofar as it is costly for others to know their behaviour' (1988: 66).

A question that we need to ask is, 'why has the structure of the firm characterized by agency costs survived in the face of such vulnerable contracts?' Fama and Jensen write that:

'Most goods and services can be produced by any form of organisation, and there is competition among organisational forms for survival in any activity. $\mathrm{Ab}$ sent fiat, the form of organisation that survives in an activity is the one that delivers the product at the lowest price while covering costs. This is the telling dimension on which the economic environment chooses among organisation forms .... An important factor in the survival of organisational form is control of agency costs...' (1983b: 327).

The structure of the firm that allows for insider trading is the most efficient form of organisation given relative prices in the economy. That, of course does not necessarily mean that every aspect of the firm is beneficial to shareholders, or to the firm itself. Fama and Jensen recognise that costs are built into the system. Insider trading regulations could attempt to reduce the agency costs inherent in the firm by limiting the scope for this activity.

\section{Conclusion}

Insider trading has its origins in the separation of ownership and control. The structure of the modern firm, while more 
efficient than competing organizational firms is not perfect, merely efficient. One of the disturbing characteristics of the modem firm is the opportunism that agents exhibit. Jensen (1989) reports that a new organizational structure is replacing the present form. This form has as one of its feawures the fact that the 'central weakness of the public corporation - the conflict between the owners and managers' has been resolved. It is interesting to note that this form of organisation precludes the possibility of insider trading.

We have seen that the proponents of insider trading are unable to provide overwhelming arguments in favour of it as an integral part of business practice. They are unable to bypass the problem of investor confidence. Insider trading can thus be characterized as an agency problem. If the achievement of 'deep and liquid markets' is a socially desirable goal then the regulation of insider trading is in the interests of society at large.

Kantor (quoted in Wixley 1990: 43) has said 'its the economists job to point out to the population that maybe they are wrong'. We submit that it is not enough to 'point out' the fallacies of human existence, but to convince them of it and to suggest credible solutions.

\section{References}

Alchian, A. \& Woodward, S. 1988. The firm is dead; long live the firm. A review of Oliver E. Williamson's The economic institutions of capitalism. J. Econ. Lit., Vol. 26: 65-79.

Arrow, K. 1969. The organisation of economic activity: Issues pertinent to the choice of market versus non-market allocation. In: The analysis and evaluation of public expenditure: The PPB system. US Joint Economic Committee: US Government Printing Office.

Benston, B. 1969. The effectiveness and effects of the SEC's accounting disclosure requirements. Henry Manne, (ed.). In: Economic policy and the regulation of corporate securities. Washington D.C.: American Enterprise Institute.

Bhana, N. 1989. JSE regulations and controls to protect investors. R. McGregor (ed.). In: The mechanics of the Johannesburg Stock Exchange. Johannesburg: Juta \& Co. Lid.

Clark, R. 1986. Corporate law. Boston/Toronto: Little Brown.

Coase, R. 1937. The nature of the furm. Economica 4: 386-405.

Demsetz, H. 1967. Toward a theory of property rights. Amer. Econ. Rev.: Papers and proceedings: 347-359.

Demsetz, H. 1969. Perfect competition, regulation and the stock market. Henry Manne (ed.). In: Economic policy and the regulation of corporate securities. Washington D.C.: American Enterprise Institute.

Demsetz, H. 1983. The structure of ownership and the theory of the firm. J. Law \& Economics, 26: 375-390.

Demsetz, H. 1986. Corporate control, insider trading, and rates of return. Amer. Econ. Rev.: Papers and Proceedings: 313-316.

Easterbrook, F. 1985. Insider trading as an agency problem. Pratt, J. \& Zeckhauser, R. (eds.). In: Principals and agents: The structure of business. Boston: Harvard Business School Press.

Faith, R., Higgins, R. \& Tollison, R. 1984. Managerial rents and outside recruitment in the Coasian firm. Amer. Econ. Rev., 74: 660-672.

Fama, E. 1980. Agency problems and the theory of the firm. J. Pol. Econ., 88: 288-307.

Fama, E. \& Jensen, M. 1983a. Separation of ownership and control. J. Law \& Economics, 26: 301-325.

Fama, E. \& Jensen, M. 1983b. Agency problems and residual claims. J. Law \& Economics, 26: 327-349.

Friend, I. 1969. Discussion and comment on papers by Professor Friend \& Professor Meltzer. Manne, H. (ed.). In: Economic policy and the regulation of corporate securities. Washington D.C.: American Enterprise Institute.

Harris, L. 1988. The regulation of insider trading. Unpublished MBA Thesis. Johannesburg: University of the Witwatersrand.

Jensen, M. 1989. Eclipse of the public corporation. Harvard Bus. Rev., September-October: 61-74.

Jensen, M. \& Meckling, W. 1976. Theory of the firm: Managerial behaviour, agency costs and ownership structure. J. Fin. Econ. 3: 305-360.

Kantor, B. 1991. In support of insider trading: More than a zero sum game. Businessman's Law, Vol. 20, No. 6: 167-170.

Klein, B. 1983. Contracting costs and residuals claims: The separation of ownership and control. J. Law \& Economics 26: 367-373.

Light, J. 1989. The privatisation of equity. Harvard Bus. Rev., September-October: 62-63.

Manne, H. 1966a. Insider trading and the stock market. New York: The Free Press.

Manne, H. 1966b. In defence of insider trading. Harvard Bus. Rev., November-December: 113-122.

Manne, H. 1970. Insider trading and the law professors. Vanderbilt Law Review 23: 547-590.

Parkman, A., George, B. \& Boss, M. 1988. Owners or traders: Who are the real victims of insider trading? J. Bus. Ethics 7: 965-971.

Ryan, C. 1988. McGregor's dictionary of stock market terms. Johannesburg: Juta \& Co. Ltd.

Schumpeter, J. 1942. Capialism, socialism and democracy. New York: Harper Brothers.

Scott, K. 1980. Insider trading: Rule 10b-5, disclosure and corporate privacy. J. Legal Studies, 9: 801-818.

Seligman, D. 1983. An economic defence of insider trading. Fortune, September, 5: 47-48.

Smith, A. 1776. The wealth of nations. Cannan edition. New York: Modem Library. 1937.

Sturc, J. 1987. Illegal insider trading - crises of confidence in financial markets. Vital Speeches, 53, 13: 404-409.

Williamson, O. 1981. The modern corporation: Origins, evolution, attributes. J. Econ. Lit. 19: 1537-1568.

Wixley, J. 1990. Inside moves. The Executive, August: 40-46. 